\title{
Antibodies Against Outer Membrane Proteins in Rabbit Antisera Prepared Against Escherichia coli O26 K60
}

\author{
By J. DANKERT AND H. HOFSTRA \\ Laboratory for Medical Microbiology, State University Groningen and \\ Division of Hospital Infections, University Hospital A.Z.G., \\ Groningen, Oostersingel 59, The Netherlands
}

(Received 15 July 1977)

\begin{abstract}
Antibodies directed against the protein constituents of the outer envelope membrane of Escherichia coli $\mathrm{O} 26 \mathrm{~K} 60$ were demonstrated in antisera elicited in rabbits against three different preparations of the bacterium. Outer membranes solubilized by sodium dodecyl sulphate were applied to the antisera in an interfacial precipitin test, followed by polyacrylamide gel electrophoretic analysis of the resulting immunecomplexes. Protein profiles showed a complete outer membrane protein pattern, indicating the antigenic character of these proteins. Antisera containing antibodies against outer membrane proteins and free of reactive antibodies against lipopolysaccharide showed relatively low agglutinating activities against the bacteria. The antibodies against the protein constituents of the outer membrane belong mainly to the $7 \mathrm{~S}$ class immunoglobulins, as indicated by 2 -mercaptoethanol treatment of the antisera.
\end{abstract}

\section{INTRODUCTION}

Gram-negative bacteria are the most frequent cause of hospital-acquired infections (Dupont \& Spink, 1969; Finland, 1970). The diversity of bacterial species and serotypes and the relative limitations of antimicrobial therapy and preventive measures, have focused the approach for control of these infections on the interactions of these Gram-negative bacteria with antibodies (McCabe, 1976). Since only type-specific antibodies to capsular (K) and lipopolysaccharide (O) antigens were protective (Kaijser, Holmgren \& Hanson, 1972), several studies have dealt with the activities of antibodies against cross-reactive bacterial antigens. Antibodies against the well known common antigen of Enterobacteriaceae, described by Kunin (1963), showed no protective activity in experimental infections (McCabe \& Greely, 1973). The walls of Gram-negative bacteria contain lipopolysaccharide at the surface layer with the lipid moiety embedded in the outer membrane. This membrane consists of protein and phospholipids, whereas lipoprotein and peptidoglycan (murein) are components of the innermost layer (Braun, 1973). The immune response against the lipid moiety of lipopolysaccharide has been evaluated, since this antigen is shared by most Enterobacteriaceae species. Protective activity of antibodies against this antigen in Gramnegative infections has been reported (Chedid et al., 1968; Ziegler et al., 1973). Mullan et al. (1974) did not find this activity, since the cross-reactive immunodeterminants on the lipid moiety of lipopolysaccharide are probably not accessible to the antibody against them ( $\mathrm{Ng}$ et al., 1976). Braun et al. (1976) have prepared antisera against lipoprotein, another common constituent of the wall of most Enterobacteriaceae species. This antigen is also buried in the outer membrane of wild-type strains and it is probable that antibodies against this antigen will not provide protective activity in Gram-negative infections. The effect of the immune response against the protein constituents of the outermost layer of the wall has 
not been described. This effect is difficult to elucidate for a number of reasons, including the heterogeneous composition and the hydrophobic character of these proteins.

The findings reported here indicate the presence of antibodies directed against the outer membrane proteins of Escherichia coli $\mathrm{O} 26 \mathrm{~K} 60$ in rabbit antisera, detected by polyacrylamide gel electrophoresis of immunoprecipitates obtained from the antisera and sodium dodecyl sulphate-solubilized outer membrane preparations.

\section{METHODS}

Bacterial strain and growth conditions. Escherichia coli, serotype $\mathrm{O} 26 \mathrm{~K} 60$, was isolated in our laboratory and typed by the Rijks Instituut voor de Volksgezondheid, Bilthoven, The Netherlands. Bacteria were maintained by monthly subcultures on agar slopes containing minimal salts and glucose. Bacteria were grown in 101 flasks under vigorous aeration at $37^{\circ} \mathrm{C}$ in liquid medium containing ( $\mathrm{g}$ per 1 deionized water): $\mathrm{Na}_{2} \mathrm{HPO}_{4}, 7.5 ; \mathrm{KH}_{2} \mathrm{PO}_{4}, 3 ; \mathrm{NaCl}, 0.5 ; \mathrm{NH}_{4} \mathrm{Cl}, 0.1 ; \mathrm{MgSO}_{4} .7 \mathrm{H}_{2} \mathrm{O}, 0.25 ; \mathrm{CaCl}_{2} .2 \mathrm{H}_{2} \mathrm{O}, 0.0015$; yeast extract, 10 ; and glucose, 5 . The final $\mathrm{pH}$ was adjusted to $7 \cdot 4$.

Isolation of outer membrane. Bacteria were grown for $3 \mathrm{~h}$. Late-exponential phase cells were harvested by centrifuging at $8000 \mathrm{~g}$ for $15 \mathrm{~min}$ at $4{ }^{\circ} \mathrm{C}$. Extracellular and flagellar materials were removed by treatment in a homogenizer (MSE) for $1 \mathrm{~min}$ in $0.05 \mathrm{M}$-Tris/ $\mathrm{HCl}$ buffer (pH 7.8) containing $0.001 \mathrm{M}$-EDTA as described by Schnaitman $(1970 a)$. After sedimentation, the sheared bacteria were frozen and disintegrated by passage three times through an X-press (Nike, Eskilstuna, Sweden). Unbroken cells were removed by low speed centrifugation. RNAase $\left(0.2 \mathrm{mg}\right.$ ), DNAase $\left(0.1 \mathrm{mg}\right.$ ) (Merck, Darmstadt, West Germany) and $\mathbf{M g C l}_{\mathbf{2}}$ (to a concentration of $0.002 \mathrm{M}$ ) were added to the supernatant. The envelope fraction was sedimented by centrifuging $\left(100000 \mathrm{~g}, 4{ }^{\circ} \mathrm{C}, 45 \mathrm{~min}\right.$; Heraeus Christ Ultracentrifuge, Osterode, West Germany) and extracted twice in $0.01 \mathrm{M}-\mathrm{N}$-2-hydroxyethylpiperazine- $N^{\prime}$-2-ethanesulphonic acid (HEPES) buffer pH 7.4 (Flow Laboratories, Irvine, Ayrshire), containing 2\%(w/v) Triton X-100 (Sigma), for $15 \mathrm{~min}$ at room temperature (Schnaitman, 1971). Each extraction was followed by cooling in ice and resedimentation $\left(100000 \mathrm{~g}, 0^{\circ} \mathrm{C}, 45 \mathrm{~min}\right)$. The Triton-extracted envelopes (outer membrane fraction) were washed twice with HEPES buffer $(\mathrm{pH} 7 \cdot 4)$ and resuspended in $0.9 \%(\mathrm{w} / \mathrm{v}) \mathrm{NaCl}$. Samples $(0.2 \mathrm{ml})$ of the outer membrane suspension, containing about $10 \mathrm{mg}$ protein, were stored at $-80^{\circ} \mathrm{C}$ (Revco Ultralow, Deerfield, Michigan, U.S.A.).

Preparation of antisera. Three groups of adult rabbits were given a series of six intravenous injections over a period of 2 weeks with one of the following three preparations of $E$. coli O26 K60: I, formaldehyde-fixed cells $\left(10^{9}\right.$ cells ml $\left.{ }^{-1}\right)$; II, formaldehyde-fixed cells sheared in Tris/EDTA, prepared as described above $\left(10^{9} \mathrm{cells}\right.$ $\left.\mathrm{ml}^{-1}\right)$; or III, Triton X-100 extracted envelopes $\left(10 \mathrm{mg} \mathrm{ml}^{-1}\right)$. Rabbits were bled by heart puncture 1 week after the last injection. Samples $(1 \mathrm{ml})$ of antisera raised against I, II or III were stored without preservative at $-80^{\circ} \mathrm{C}$.

Absorption of antisera. Antibodies directed against E. coli $\mathrm{O} 26$ lipopolysaccharide (LPS) were removed from the sera by stepwise addition of a concentrated solution containing purified LPS $026\left(10 \mathrm{mg} \mathrm{ml}^{-1}\right.$; Difco). Soluble complexes are not formed if LPS is present in excess (Rowley \& Turner, 1966). Usually about $0.8 \mathrm{mg}$ LPS was added to $1 \mathrm{ml}$ of the antiserum. The absence of reactive antibodies against LPS was tested by immunodiffusion in agarose using the purified antigen and the appropriate absorbed antiserum. To remove antibodies against the antigenic determinants of the bacterial surface, antisera were incubated with a dense suspension of living bacteria for $2 \mathrm{~h}$ at $37^{\circ} \mathrm{C}$ followed by centrifuging at $8000 \mathrm{~g}$ for $15 \mathrm{~min}$ at $4{ }^{\circ} \mathrm{C}$. To remove antibodies against surface antigenic structures except flagellar ( $\mathrm{H}$ antigen) and capsular material ( $\mathrm{K}$ antigen), antisera were absorbed in the same way using Tris/EDTA-sheared bacteria.

Mercaptoethanol treatment. In order to reduce immunoglobulin M, LPS-absorbed antisera were treated with 0.2 M-2-mercaptoethanol as described by Holmgren (1970).

Agglutination test. In agglutination tests, formaldehyde-fixed E. coli $\mathrm{O} 26 \mathrm{~K} 60$ or Tris/EDTA-sheared bacteria in $0.9 \%(\mathrm{w} / \mathrm{v}) \mathrm{NaCl}\left(10^{9}\right.$ cells $\left.\mathrm{ml}^{-1}\right)$ were used as test organisms. Twofold serum dilution series were made in phosphate-buffered saline (PBS). To $0.2 \mathrm{ml}$ of diluted serum an equal volume of the bacterial suspension was added in a microtest tube. Agglutination was read after incubation for $5 \mathrm{~h}$ at $37^{\circ} \mathrm{C}$ followed by $10 \mathrm{~h}$ at $4{ }^{\circ} \mathrm{C}$. The highest serum dilution giving total agglutination was recorded. No auto-agglutination was observed in tubes containing bacteria only, nor did any agglutination occur when serial dilutions of pre-immunization sera were added to the cell suspensions. Agglutination tests were carried out with dilution series of antisera I, II and III, of LPS-immunoprecipitated antisera I, II and III and of these sera after 2-mercaptoethanol treatment. Antisera I, II and III absorbed with living cells or with Tris/EDTAsheared bacteria were also tested.

Immunoprecipitation test. Outer membrane (OM) samples were dispersed in $2 \mathrm{ml}$ PBS to which sodium dodecyl sulphate (SDS) was subsequently added to a final concentration of 0.15 to $0.20 \%(\mathrm{w} / \mathrm{v})$, depending 
on the solubility of the sample. Sonication for 10 to $20 \mathrm{~s}$ (Branson Ultrasonics, Soest, The Netherlands) usually resulted in a clear solution.

To prevent non-specific precipitation of reconstituted membrane complexes (Sekizawa \& Fukui, 1973), SDS (final concentration $0.15 \%$, w/v) was added to the antisera, which were diluted fourfold with PBS. From the solution containing the $\mathrm{OM}$ fraction, $0.2 \mathrm{ml}$ was carefully pipetted on to an equal volume of serum in a microtest tube. After incubation for 30 min at $37^{\circ} \mathrm{C}$, the interfacial precipitation reactions were examined. After another $2 \mathrm{~h}$ incubation, the precipitates were sedimented $\left(20 \mathrm{~min}, 10000 \mathrm{~g}, 4^{\circ} \mathrm{C}\right)$, washed twice with $0.9 \%(\mathrm{w} / \mathrm{v}) \mathrm{NaCl}$ containing $0.15 \%(\mathrm{w} / \mathrm{v}) \mathrm{SDS}$ and stored at $-20^{\circ} \mathrm{C}$ until required for analysis on polyacrylamide gels. Immunoprecipitation tests were carried out using the antisera (I, II and III) and these sera after LPS absorption. Pre-immunization sera and antisera absorbed with living $E$. coli were applied as controls.

SDS-polyacrylamide gel electrophoresis. $\mathrm{OM}$ fractions and immunoprecipitates were analysed on polyacrylamide gels. Two methods of SDS-polyacrylamide gel electrophoresis (PAGE) were used. A single gel system according to Weber \& Osborn (1969) was applied using $0.5 \times 10 \mathrm{~cm}$ gels of $10 \%(\mathrm{w} / \mathrm{v})$ polyacrylamide in $0.01 \mathrm{M}$-sodium phosphate buffer $\mathrm{pH} 7.3$ and $0.1 \%(\mathrm{w} / \mathrm{v})$ SDS. Samples of OM fractions or immunoprecipitates, containing about $100 \mu \mathrm{g}$ protein, were dissolved in $0.01 \mathrm{M}$-phosphate buffer $\mathrm{pH} 7.3$ containing $1 \%(\mathrm{w} / \mathrm{v})$ SDS, $2 \%(\mathrm{v} / \mathrm{v}) 2$-mercaptoethanol, $10 \%(\mathrm{v} / \mathrm{v})$ glycerol and $0.5 \%(\mathrm{w} / \mathrm{v})$ bromophenol blue and boiled for $5 \mathrm{~min}$ before application to the gels. Electrophoresis was carried out for $12 \mathrm{~h}$ at $5 \mathrm{~mA}$ per gel. Gels were stained with $0.04 \%(\mathrm{w} / \mathrm{v})$ Coomassie brilliant blue in water/acetic acid/2-propanol $(6 \cdot 5: 1: 2 \cdot 5$, by vol.) and destained in water/acetic acid/2-propanol (8:1:1, by vol.). Gels were stored in test-tubes containing destaining solution at $4{ }^{\circ} \mathrm{C}$. As a second method, a discontinuous buffer system according to Laemmli (1970) was applied on slab gels, prepared as described by Ames (1974). The upper (spacer) gel contained $3 \%(\mathrm{w} / \mathrm{v})$ polyacrylamide in $0.0125 \mathrm{M}$-Tris/ $\mathrm{HCl}$ buffer $\mathrm{pH} 6.7$, and the lower (separating) gel contained $12 \%(\mathrm{w} / \mathrm{v}$ ) polyacrylamide in $0.0375 \mathrm{M}$-Tris/ $\mathrm{HCl}$ buffer $\mathrm{pH} 8.9$. Both gels contained $1 \%(\mathrm{w} / \mathrm{v})$ SDS. Samples were prepared as described above, but Tris/HCl buffer $(0.0125 \mathrm{M}, \mathrm{pH} 6.7)$ was used instead of phosphate buffer and the SDS concentration was $5 \%(\mathrm{w} / \mathrm{v})$, After application of the samples (30 to $50 \mu \mathrm{l}$ per gel), electrophoresis was run for 4 to $5 \mathrm{~h}$ at $18 \mathrm{~mA}$. Gels were stained and destained as described above.

Stained gels were photographed on Agfa Ortho 25 Professional document copying film. Cytochrome $c$, mol. wt 11700 (Sigma), ribonuclease, mol. wt 13700 (Merck), ovalbumin, mol. wt 43000 (Sigma), bovine serum albumin, mol. wt 68000 (Sigma) and $\beta$-galactosidase, mol. wt 130000 (Sigma) were used as standard proteins for molecular weight estimation in both systems. In the analysis of immunoprecipitates, rabbit immunoglobulins (Schwarz Mann, New York, U.S.A.) were also applied as standard proteins.

Chemical determinations. Protein was estimated with the Folin-Ciocalteu reagent according to Lowry et al. (1951). In the presence of Triton X-100 or other detergents, the microbiuret method (Goa, 1953) was used.

\section{RESULTS}

\section{Outer membrane protein profiles of $E$. coli $\mathrm{O} 26 \mathrm{~K} 60$}

Proteins of the outer membrane (OM) fractions prepared by repeated Triton X-100 extraction of the total envelope of $E$. coli $\mathrm{O} 26 \mathrm{~K} 60$ were analysed by the methods of Weber \& Osborn (1969) and of Laemmli (1970). The profile obtained by the first method (Fig. $1 a$ ) is in agreement with previously described patterns (Bragg \& Hou, 1972; Uemura \& Mizushima, 1975). The 37000 to 39000 dalton band is identical to the major protein complex of Schnaitman $(1970 a, b)$, to protein $A_{1}$ of Bragg \& Hou (1972) and to the matrix protein of Rosenbusch (1974). The band with an electrophoretic mobility corresponding to a molecular weight of 16000 is probably protein III of Henning, Höhn \& Sonntag (1973) and the 7500 dalton band resembles their protein IV. This last band shows a reddish purple colour (Uemura \& Mizushima, 1975) and is identical to the lipoprotein of Braun \& Rehn (1969). Minor protein bands, which have been noticed and described before (Bragg \& Hou, 1972; Uemura \& Mizushima, 1975), were also seen. The outer membrane protein profile obtained by the method of Laemmli (1970) on slab gel (Fig. $1 b$ ) shows that the major protein of Schnaitman $(1970 a, b)$ is divided into three distinct protein bands, with apparent molecular weights ranging from 33000 to 39000 . Lugtenburg et al. (1975) resolved the major OM protein of $E$. coli $\mathrm{K} 12$ into four bands (a, b, c and d). Their band a is probably not visible in our profile. The lower one of these bands represents a heat-modifiable protein, described as protein $\mathrm{II}^{*}$ by Garten, Hindennach \& Henning (1975). Protein III of Henning et al. (1973) 


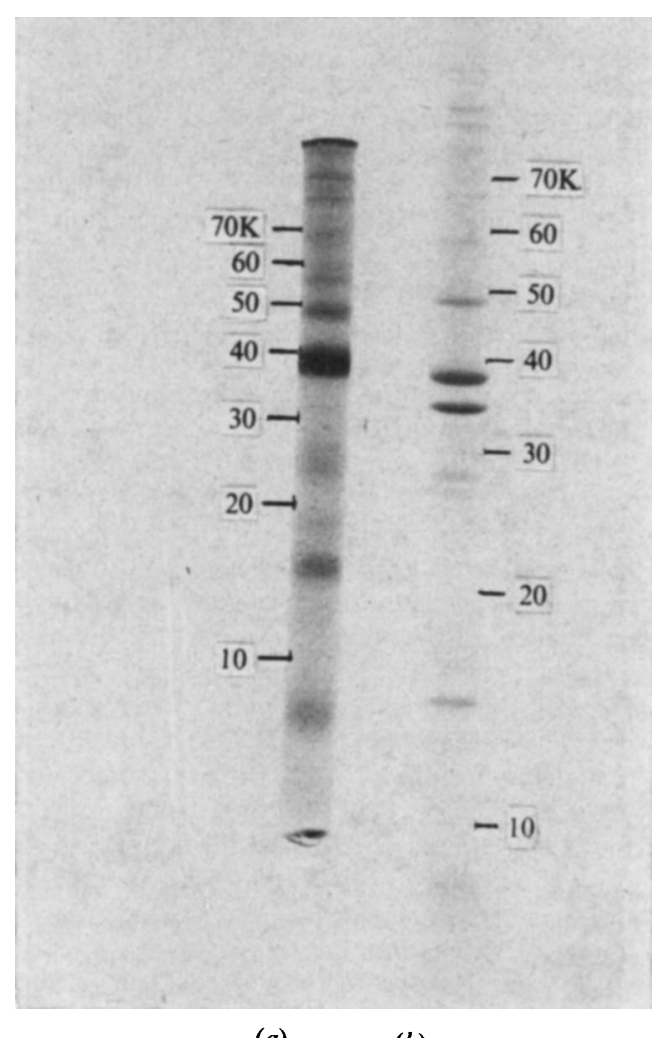

(a)

(b)

Fig. 1. Electrophoretic patterns of $E$. coli $\mathrm{O} 26 \mathrm{~K} 60$ outer membrane proteins: (a) analysed according to Weber \& Osborn (1969) in vertical glass tubes; $(b)$ analysed using a discontinuous buffer system according to Laemmli (1970) on slab gel. Molecular weights are indicated beside the protein profiles.

is visible as a clear band at a position corresponding to a molecular weight of 16000 . The 7500 dalton lipoprotein, which is often covered by the bromophenol blue marker when the discontinuous gel technique of Laemmli (1970) is used, can be seen in our profile.

\section{Agglutination tests}

Rabbit antisera I, II and III, prepared against formaldehyde-fixed E. coli O26 K60, Tris/EDTA-sheared cells or isolated outer membrane fractions, respectively, showed total agglutination against formaldehyde-fixed cells and against Tris/EDTA-sheared bacteria in serum dilutions up to $1: 8000$ (Table $1 a$ ). Using antisera which had been quantitatively precipitated with purified LPS (prepared from E. coli O26), a significant decrease in agglutination titres was found (Table $1 b$ ). The agglutinates formed in these sera showed a cloudy and flocculant appearance comparable to the agglutinates found in the conventional $\mathrm{H}$ agglutination, but were easily distinguishable from the granular O-specific agglutinate. The possibility that antibodies directed against flagella ( $\mathrm{H}$ antigen) were involved in the agglutination was exluded by carrying out the test with Tris/EDTA-sheared cells. The results were practically identical to those obtained with whole formaldehyde-fixed cells (Table $1 b$ ). Agglutinating activity was not decreased in antisera containing no reactive antibodies against LPS and subsequently treated with 2-mercaptoethanol (Table $1 c$ ). This activity against formaldehyde-fixed cells was fully abolished in antisera quantitatively 
Table 1. Agglutinating activity in antisera raised against formaldehyde-fixed E. coli $\mathrm{O} 26 \mathrm{~K} 60$ (I), formaldehyde-fixed and Tris/EDTA-sheared bacteria (II) and isolated outer membrane of E. coli $\mathrm{O} 26 \mathrm{~K} 60$ (III)

Antiserum

(a) Unabsorbed<smiles>[AlH]</smiles>

II

III

(b) LPS-precipitated

I

II

III

(c) LPS-precipitated and treated with 2-mercaptoethanol

I

II

III

(d) LPS-precipitated and absorbed

to whole $E$. coli $\mathrm{O} 26$ cells

I

II

III

(e) LPS-precipitated and absorbed

to Tris/EDTA-sheared E. coli O26

cells

I

III
Agglutinating activity against E. coli $\mathrm{O} 26 \mathrm{~K} 60$

$\overbrace{\begin{array}{c}\text { Formaldehyde-fixed } \\ \text { whole cells }\end{array}}^{\begin{array}{c}\text { Formaldehyde-fixed } \\ \text { and Tris/EDTA- } \\ \text { sheared cells }\end{array}}$

$\begin{array}{ll}4000 & 8000 \\ 2000 & 4000 \\ 4000 & 4000\end{array}$

$\begin{array}{rr}128 & 256 \\ 64 & 128 \\ 128 & 128\end{array}$

128

128

128

128

128

$\begin{array}{ll}<4 & \text { ND } \\ <4 & \text { ND } \\ <4 & \text { ND }\end{array}$

$<4 \quad$ ND

$<4 \quad$ ND

ND, Not done.

precipitated with LPS and absorbed with whole cells (Table $1 d$ ). The same result was obtained in antisera treated with LPS and subsequently absorbed with Tris/EDTA-sheared cells (Table $1 e$ ). This finding excludes once again the possibility that antibodies against flagellar components were involved in the formation of the agglutinate.

\section{Interfacial precipitin test and immunecomplex analysis}

Antisera I, II and III were used in immunoprecipitation experiments carried out as described in Methods. Pre-immunization sera of all rabbits (in which antisera were raised) were negative in this test, whereas application of the antisera always resulted in a heavy precipitation reaction immediately upon addition of the solubilized OM fraction of $E$. coli O26 K60. Using antisera free of reactive antibodies against LPS, significantly less precipitate was formed in the interface, although a clearly visible precipitation ring could always be seen. In antisera absorbed with whole bacteria no precipitates were formed. The same results were obtained after absorption with heat-killed and formaldehyde-treated bacteria. Immunoprecipitates were sedimented, washed and analysed as described in Methods. Figure 2 $(a, b, c)$ shows the Weber \& Osborn PAGE profiles of immunoprecipitates of solubilized OM and unabsorbed antisera I, II and III. In these profiles, proteins of the outer membrane are found as well as protein bands not originating from the microbial envelope. The major protein band of the OM (37000 to 39000 dalton) was always present in the protein profile. Bands corresponding to the 16000 and the 7500 dalton proteins were rather 


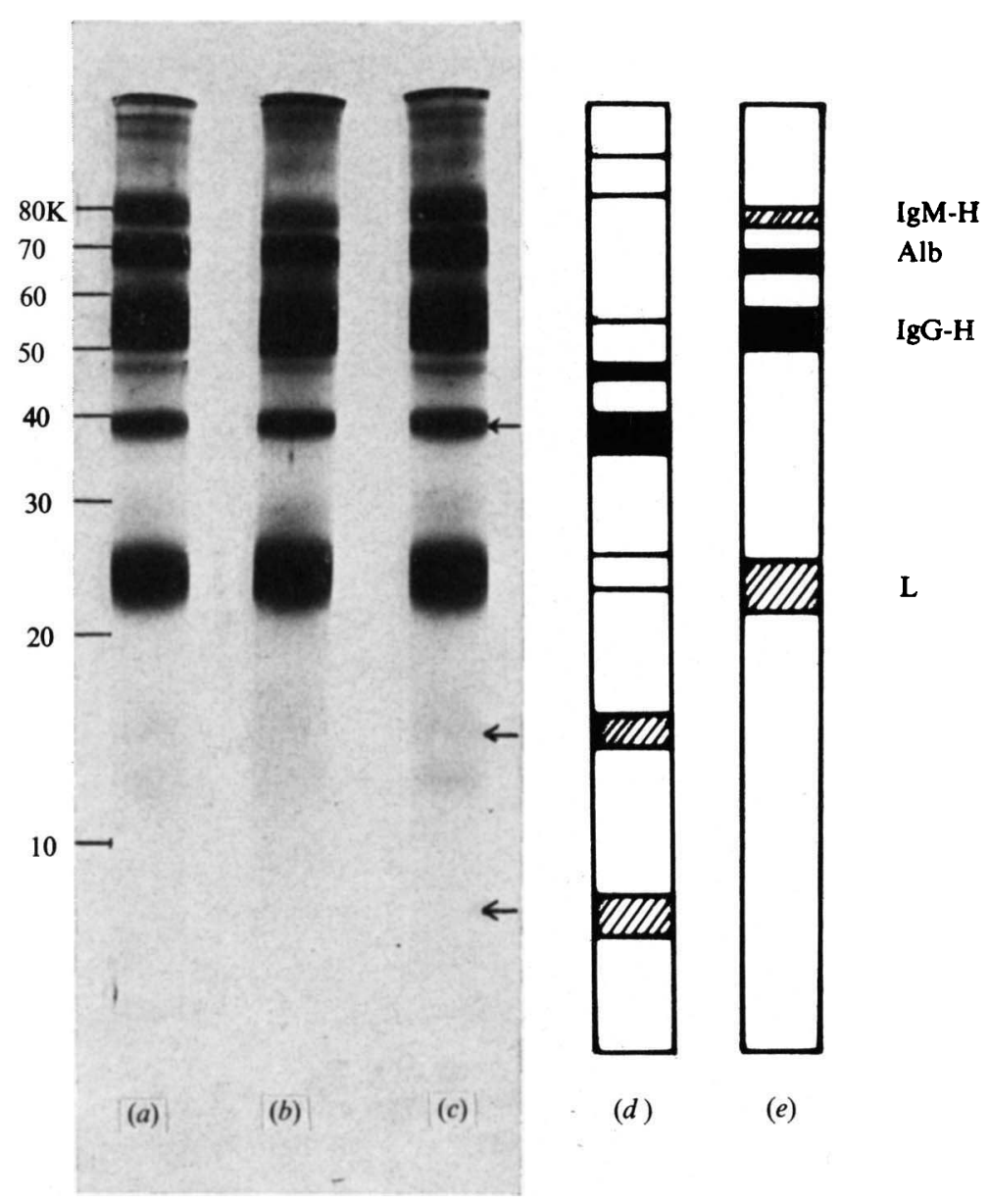

Fig. 2. Electrophoretic patterns of immunoprecipitates analysed according to Weber \& Osborn (1969). Precipitates were obtained in interfacial precipitin tests, carried out with SDS-solubilized E. coli $\mathrm{O} 26 \mathrm{~K} 60$ outer membranes and rabbit antisera containing $0 \cdot 15 \%(\mathrm{w} / \mathrm{v}) \mathrm{SDS}$. Antisera were raised against: $(a)$ formaldehyde-fixed whole bacteria; $(b)$ formaldehyde-fixed and Tris/EDTAsheared bacteria; $(c)$ isolated outer membranes. Proteins originating from the outer membrane are indicated by arrows on the right. A control gel of the outer membrane is shown in $(d)$. Nonmicrobial bands in the immunoprecipitates correspond to heavy and light chains of rabbit immunoglobulins and albumin in the sera, as indicated in a control gel of rabbit IgG, IgM and albumin (e). (IgM-H, heavy chains of IgM; Alb, albumin; IgG-H, heavy chains of IgG; L, light chains of immunoglobulins).

diffuse, though always visible when gels were freshly stained. PAGE profiles of the immunoprecipitates obtained with the different antisera showed no evident differences. The nonmicrobial bands correspond to the heavy and light chains of rabbit immunoglobulins (Stanworth \& Turner, 1973) and albumin in the sera.

Protein profiles resulting from the immunoprecipitates analysed by the method of Laemmli (1970) on slab gels are shown in Fig. 3( $a, b, c)$. Except for the dense bands corresponding to the rabbit immunoglobulins and some albumin, a complete pattern of E. coli O26 OM proteins is present. The major proteins in the 33000 to 39000 dalton range as well as the 16000 dalton protein (Henning's protein III) appear as clearly visible bands. Some of the minor proteins were often detectable. To exclude the possibility that LPS-linked OM protein immunoprecipitates were formed, purified LPS of $E$. coli O26 was added stepwise to the antisera as described in Methods. Samples of these sera subsequently tested against 


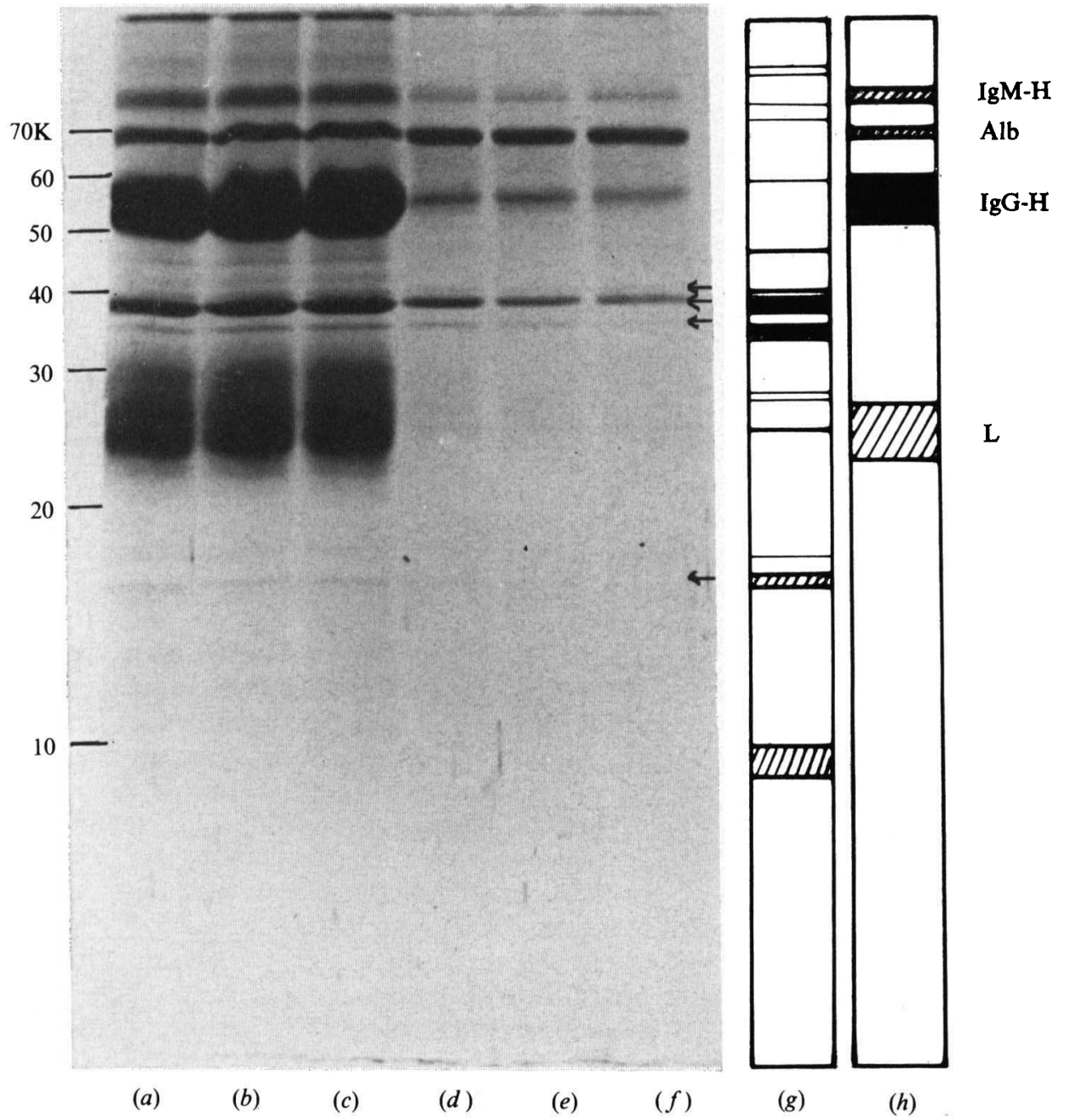

Fig. 3. Electrophoretic patterns of immunoprecipitates analysed according to Laemmli (1970). Precipitates were obtained in interfacial precipitin tests carried out with SDS-solubilized $E$. coli O26 K60 outer membranes and rabbit antisera containing $0 \cdot 15 \%(w / v)$ SDS. Antisera were raised against: $(a)$ and $(d)$ formaldehyde-fixed bacteria, $(b)$ and $(e)$ formaldehyde-fixed and Tris/EDTA-sheared bacteria; $(c)$ and $(f)$ isolated outer membranes. In $(a),(b)$ and $(c)$ unabsorbed antisera were applied, and in $(d),(e)$ and $(f)$ sera were freed of reactive antibodies against lipopolysaccharide (LPS) by stepwise addition of purified LPS. Proteins originating from the outer membrane are indicated by arrows on the right. A control gel of the normal outer membrane is shown in $(g)$. Non-microbial bands in the immunoprecipitates correspond to albumin and the heavy and light chains of rabbit immunoglobulins in the sera, as indicated in a control gel of rabbit IgG, IgM and albumin $(h)$. Abbreviations as in Fig. 2.

this antigen in agarose immunodiffusion tests showed the absence of active antibodies against LPS. PAGE profiles of immunoprecipitates obtained from these antisera and the solubilized OM preparation showed a marked decrease in the density of immunoglobulin bands (Fig. $3 d, e, f$ ). On the other hand, the OM protein bands were all present, but a slight decrease in density was found in comparison with those obtained from immunoprecipitates formed in unabsorbed antisera. 


\section{DISCUSSION}

PAGE analysis of immunoprecipitates of outer membrane (OM) preparations from the wall of E. coli $\mathrm{O} 26 \mathrm{~K} 60$ and antiserum I, II or III, obtained in the interfacial immunoprecipitation test, showed all major proteins of the outer membrane. This indicates that antibodies directed against these constituents of the OM were present in the sera. The antisera were raised against formaldehyde-fixed $E$. coli $\mathrm{O} 26 \mathrm{~K} 60$, formaldehyde-fixed cells sheared in Tris/EDTA and isolated OM in adult rabbits. Agglutination tests with these antisera suggested the presence of antibodies, not directed against LPS (O antigen), flagellar components ( $\mathrm{H}$ antigen) or capsular material (K antigen) of $E$. coli $\mathrm{O} 26 \mathrm{~K} 60$. Except for these structures at the microbial surface, the wall of $E$. coli consists mainly of protein and phospholipids of the OM, and lipoprotein and peptidoglycan (murein) components of the rigid inner layer (Braun, 1973). The structure of the OM of Gram-negative bacteria is maintained by strong hydrophobic interactions between the constituents. This requires the application of ionic detergents such as SDS to solubilize the membrane and to prevent reaggregation of the dissociated components (Sekizawa \& Fukui, 1973). The use of these ionic detergents strongly interferes with the formation of precipitation lines in immunochemical techniques such as immunodiffusion or immunoelectrophoresis, which are based on water solubility of the reacting antigen. Therefore it is not yet possible to investigate the role of OM proteins of most Gram-negative micro-organisms as surface antigens with these techniques (Salton \& Owen, 1976). To overcome this hindrance, we used an immunoprecipitation ring test, carried out with SDS-solubilized OM preparations and antisera containing $0 \cdot 15 \%(\mathrm{w} / \mathrm{v})$ SDS. The application of SDS at concentrations up to $0.2 \%(\mathrm{w} / \mathrm{v})$ has been reported previously for immunoprecipitation experiments to determine antibodies against the free lipoprotein of the $E$. coli wall (Inouye et al., 1976). This method appeared to be very specific since only lipoprotein was found as a single peak in PAGE-analysed immunoprecipitates which were obtained when total OM solubilized by $0 \cdot 2 \%(\mathrm{w} / \mathrm{v})$ SDS was added to an antiserum raised against purified lipoprotein. In our study, PAGE-analysed immunecomplexes, obtained with three antisera and solubilized OM, show the complete protein profile of the OM of E. coli O26. Application of pre-immunization sera or antisera absorbed with whole $E$. coli $\mathrm{O} 26$ in these experiments did not result in precipitation of outer membrane proteins, indicating the specificity of our findings.

Some of the OM proteins of $E$. coli and other Gram-negative bacteria show important differences in their electrophoretic mobilities on SDS-polyacrylamide gels, depending on the temperature of solubilization. This phenomenon, probably due to incomplete unfolding of the polypeptide chains (Schnaitman, 1973), has been described for some of the OM proteins of Gram-negative bacteria (Ames, Spudich \& Nikaido, 1974; Garten et al., 1975). In our study the immunecomplexes were boiled in $5 \%(\mathrm{w} / \mathrm{v})$ SDS for $5 \mathrm{~min}$ before PAGE analysis, which results in a profile of fully unfolded polypeptide chains of OM proteins. In the precipitation tests however, immunecomplexes were formed under relatively mild conditions $\left[37^{\circ} \mathrm{C}, 0.2 \%(\mathrm{w} / \mathrm{v}) \mathrm{SDS}\right]$. Therefore we cannot exclude the possibility that $\mathrm{OM}$ constituents were involved in the immunoprecipitation as undissociated complexes and not as the separate polypeptide chains as suggested by the results of PAGE-analysed immunoprecipitates.

One of the complications in a study concerning the immune response of OM proteins of Gram-negative bacteria is the presence of LPS as a surface component. Using LPSunabsorbed antisera in the immunoprecipitation experiments, LPS-linked OM protein immunecomplex formation will occur, since all OM proteins are contaminated with the highly antigenic LPS (Hindennach \& Henning, 1975). In fact, significantly less immunoprecipitate was formed when antisera free of reactive antibodies against LPS were used. This was mainly due to the absence of LPS-anti-LPS complexes. However, PAGE profiles of these precipitates showed a small, but nevertheless evident reduction of the OM protein 
content, in comparison with that obtained in the immunoprecipitates formed in LPSunabsorbed antisera. This finding indicates that some of the OM proteins were involved in the immunoprecipitation reaction as LPS-containing complexes. On the other hand, immunecomplexes were formed with $\mathrm{OM}$ proteins and their appropriate antibodies, suggesting the antigenic character of these outer membrane constituents.

Until now, only antibodies against the lipoprotein of the outer membrane of $E$. coli and other Enterobacteriaceae had been reported (Braun et al., 1976; Inouye et al., 1976). Antibodies against the hydrophobic protein constituents of the outermost layer of these bacterial walls had not been described. We found that antisera containing these antibodies showed relatively low agglutinating activity against the appropriate micro-organism. When the antisera were treated with 2-mercaptoethanol, this activity was not reduced, indicating that the antibodies mainly belong to the $7 \mathrm{~S}$ class immunoglobulins. These antibodies can be used after purification in ferritin-labelled antibody techniques for studying the ultrastructure of the OM and the distribution of surface exposed proteins. Their biological significance, either for diagnostic purposes or for protective activity against infections produced by homologous or even heterologous strains, awaits evaluation.

The authors are grateful to $\mathrm{Mr} \mathrm{R}$. W. Rozeboom for his skilful technical assistance.

\section{REFERENCES}

Ames, G. F. (1974). Resolution of bacterial proteins by polyacrylamide gel electrophoresis on slabs. Membrane, soluble, and periplasmic fractions. Journal of Biological Chemistry 249, 634-644.

Ames, G. F., Spudich, E. N. \& Nikaido, H. (1974). Protein composition of the outer membrane of Salmonella typhimurium: effect of lipopolysaccharide mutation. Journal of Bacteriology 117, 406-416.

BragG, P. D. \& Hou, C. (1972). Organization of proteins in the native and reformed outer membrane of Escherichia coli. Biochimica et biophysica acta 274, 478-488.

BRAUN, V. (1973). Molecular organization of the rigid layer and the cell wall of Escherichia coli. Journal of Infectious Diseases 128 suppl., S9-S16.

Braun, V. \& ReHN, K. (1969). Chemical characterization, spatial distribution and function of a lipoprotein (murein-lipoprotein) of the $E$. coli cell wall. The specific effect of trypsin on the membrane structure. European Journal of Biochemistry 10, 426-438.

Braun, V., Bosch, V., Klumpp, E. R., NefF, I., MAYeR, H. \& Schlecht, S. (1976). Antigenic determinants of murein lipoprotein and its exposure at the surface of Enterobacteriaceae. European Journal of Biochemistry 62, 555-566.

Chedid, L., Parant, M., Parant, F. \& Boyer, F. (1968). A proposed mechanism for natural immunity to enterobacterial pathogens. Journal of Immunology 100, 292-301.

DuponT, H. L. \& SPINK, W. W. (1969). Infections due to Gram-negative organisms: an analysis of 860 patients with bacteremia at the University of Minnesota Medical Center 1958-1966. Medicine 48, 307-332.

FINLAND, M. (1970). Changing ecology of bacterial infections as related to antibacterial therapy. Journal of Infectious Diseases 122, 419-431.

Garten, W., Hindennach, I. \& Henning, U. (1975).
The major proteins of the Escherichia coli outer cell envelope membrane. Characterization of proteins II and III, comparison of all proteins. European Journal of Biochemistry 59, 215-221.

GoA, J. (1953). Microbiuret method for protein determination. Determination of total protein in cerebrospinal fluid. Scandinavian Journal of Clinical and Laboratory Investigation 5, 218222.

Henning, U., Höhn, B. \& Sonntag, I. (1973). Cell envelope and shape of Escherichia coli $\mathrm{k} 12$. The ghost membrane. European Journal of Biochemistry 39, 27-36.

HindennaCH, I. \& HenNing, U. (1975). The major proteins of the Escherichia coli outer cell envelope membrane. Preparative isolation of all major membrane proteins. European Journal of Biochemistry 59, 207-213.

Holmgren, J. (1970). The antibody response in rabbits to $E$. coli $\mathrm{O}$ antigen. International Archives of Allergy and Applied Immunology 37, 546-559.

Inouye, S., TAKeishi, K., Lee, N., De Martini, M., Hirashima, A. \& INOUYE, M. (1976). Lipoprotein from the outer membrane of Escherichia coli: purification, paracrystallization, and some properties of its free form. Journal of Bacteriology 127, 555-563.

KaiJser, B., Holmgren, J. \& Hanson, L. (1972). The protective effect against $E$. coli of $\mathrm{O}$ and $\mathrm{K}$ antibodies of different immunoglobulin classes. Scandinavian Journal of Immunology 1, 27-32.

KuniN, C. M. (1963). Separation, characterization, and biological significance of a common antigen in Enterobacteriaceae. Journal of Experimental Medicine 118, 565-586.

LAEMMLI, U. K. (1970). Cleavage of the structural proteins during the assembly of the head of bacteriophage T4. Nature, London 227, 680-685.

Lowry, O. H., Rosebrough, N. J., FARR, A. L. \& RANDALL, R. J. (1951). Protein measurement with 
the Folin phenol reagent. Journal of Biological Chemistry 193, 265-275.

Lugtenberg, B., Meyers, J., Peters, R., Van Der HoEk, P. \& VAN AlPhen, L. (1975). Electrophoretic resolution of the "Major outer membrane protein' of Escherichia coli $\mathrm{k} 12$ into four bands. FEBS Letters 58, 254-258.

MCCABE, W. R. (1976). Immunoprophylaxis of Gram-negative bacillary infections. Annual Review of Medicine 27, 335-341.

McCabe, W. R. \& Greely, A. (1973). Common Enterobacterial Antigen. II. Effect of immunization on challenge with heterologous bacilli. Infection and Immunity 7, 386-392.

Mullan, N. A., Newsome, P. M., Cunnington, P. G., Palmer, G. H. \& Wilson, M. E. (1974). Protection against Gram-negative infections with antiserum to lipid A from Salmonella minnesota R595. Infection and Immunity 10, 1195-1201.

NG, A. K., Chen, C. H., Chang, C. M.\& Nowotny, A. (1976). Relationship of structure to function in bacterial endotoxins: serologically cross-reactive components and their effect on protection of mice against some Gram-negative infections. Journal of General Microbiology 94, 107-116.

RosenbusCH, J. R. (1974). Characterization of the major envelope protein from Escherichia coli. Regular arrangement on the peptidoglycan and unusual dodecyl sulfate binding. Journal of Biological Chemistry 249, 8019-8029.

RowleY, D. \& TURNER, K. J. (1966). Number of molecules of antibody required to promote phagocytosis of one bacterium. Nature, London 210, 496-498.

Salton, M. R. J. \& Owen, P. (1976). Bacterial membrane structure. Annual Review of Microbiology 30, 451-482.

Schnaitman, C. A. $(1970 a)$. Examination of the protein composition of the cell envelope of Escherichia coli by polyacrylamide gel electrophoresis. Journal of Bacteriology 104, 882-889.
SChnaitman, C. A. $(1970 \mathrm{~b})$. Protein composition of the cell wall and cytoplasmic membrane of Escherichia coli. Journal of Bacteriology 104, 890901.

Schnaitman, C. A. (1971). Effect of ethylenediaminetetraacetic acid, Triton X-100, and lysozyme on the morphology and chemical composition of isolated cell walls of Escherichia coli. Journal of Bacteriology 106, 553-563.

Schnaitman, C. A. (1973). Outer membrane proteins of Escherichia coli. I. Effect of preparative conditions on the migration of protein in polyacrylamide gels. Archives of Biochemistry and Biophysics 157, 541-552.

Sekizawa, J. \& FukUI, S. (1973). Isolation, solubilization and reaggregation of outer membrane of Escherichia coli. Biochimica et biophysica acta 307, $104-117$.

StanWorth, D. R. \& TuRner, M. W. (1973). Immunochemical analysis of immunoglobulins and their subunits. In Handbook of Experimental Immunology, vol. I, Immunochemistry, pp. 10.110.97. Edited by D. M. Weir, Oxford: Blackwell Scientific Publications.

Uemura, J. \& Mizushima, S. (1975). Isolation of outer membrane proteins of Escherichia coli and their characterization on polyacrylamide gel. Biochimica et biophysica acta 413, 163-176.

WEBER, K. \& OsBORN, M. (1969). The reliability of molecular weight determinations by dodecyl sulfate-polyacrylamide gel electrophoresis. Journal of Biological Chemistry 244, 4406-4412.

Ziegler, E. J., Douglas, H., Sherman, J. E., Davis, C. E. \& Braude, A. I. (1973). Treatment of $E$. coli and Klebsiella bacteremia in agranulocytic animals with antiserum to a UDP-gal epimerasedeficient mutant. Journal of Immunology 111, 433-438. 